\title{
Poaceae communities in the savannas of the Amazon Estuary in Brazil
}

\author{
Antônio Elielson Sousa Rocha ${ }^{1,2}$ and Izildinha Souza Miranda ${ }^{3}$
}

Received: October 9, 2012. Accepted: May 27, 2014

\begin{abstract}
We sought to identify the major environmental factors that affect the diversity and distribution of Poaceae in the savannas of the Amazon Estuary. The study was conducted across seven areas of savanna in the Amazon Estuary, within which 160 subplots of $1 \mathrm{~m}^{2}$ each were established within four $10 \times 100 \mathrm{~m}$ plots. Soil samples were collected at a depth of 0-20 cm. A total of 24 Poaceae species were recorded. Only two were common to all of the areas studied (Axonopus aureus P. Beauv. and Anthaenantia lanata (Kunth) Benth). The edaphic factors that most influenced the Poaceae in the savannas studied were organic matter, coarse sand, and silt contents. Conversely, rainfall had no effect. The floristic and structural characteristics of the savannas studied suggest that Poaceae communities exhibit low diversity and a peculiar distribution pattern in which a group of species predominate in a given stretch, creating a homogeneous physiognomy. Our findings suggest that the structure of these communities is related to a gradient of soil texture, the percentage of Axonopus and Trachypogon coverage increasing and decreasing, respectively, along that gradient. These data can contribute to the understanding of plant-soil interactions in this environment, promoting strategies for conservation, management, and revegetation.
\end{abstract}

Key words: Amazon, grasses, Panicoideae, plant-soil interactions, Poaceae

\section{Introduction}

Throughout the Atlantic zone of the Amazon Estuary between the Amazon Rainforest and the coast, there are patches of savanna, commonly known as campos ("fields"). These areas are part of a complex mosaic along the coastline resulting from the extraordinary amount of fine and clayey sediments deposited by the Amazon River (Ab'Saber 2002). According to Rossetti et al. (2010), the landscape in the region shows the changes that have occurred in the physical environment due to the reactivation of tectonic faults during the late Quaternary, supporting a dynamic history of paleochannel abandonment, which regulated several inter-related parameters (soil type, topography, and hydrology). The expansion of these savannas might be linked to environmental changes that occurred during the Holocene, such as those related to coastal progradation due to sea level changes and alterations caused by anthropic activities, such as the use of fire (Toledo \& Bush 2007). Within this mosaic, there are patches of savanna between the Amazon Rainforest and the Atlantic coast, from the city of Calçoene in the state of Amapá to the city of Maracanã in northeast Pará, containing soil that is deep to moderately deep and moderately to well drained, varying in texture with low to very low fertility. The northern part of Amapá also features concretions of various diameters (Alves et al. 1992). Similar areas of open vegetation are found in other parts of the Amazon region. Those areas vary in size and exhibit distinct flora (Miranda \& Carneiro-Filho 1994). However, despite their distance from the savannas in Central Brazil, they also show floristic and physiognomic similarities (Ratter et al. 1996).

Soil type is one of the most important abiotic factors that affect the distribution of plant species in this ecosystem (Ratter et al. 1996; Miranda et al. 2003). Specifically, the soil texture and aluminum concentration is the main factor responsible for variation (Miranda \& Absy 2000; Miranda et al. 2003), which can only occasionally be explained by the chemical composition (Beard 1953; Ruggiero et al. 2002; Rossetti et al. 2010).

Nearly every study on abiotic factors in savannas examines the woody stratum, although the subshrub and herbaceous strata are responsible for a significant part of the richness. Poaceae often present the largest number of species, including the forage that sustained the livestock industry in the Amazon region until the beginning of the 1960s (Castro et al. 1999; Camarão \& Souza Filho 1999).

Despite the ecological and economic importance of grasses, there have been few studies addressing grass spe-

\footnotetext{
${ }^{1}$ Coordenação Botânica, Museu Paraense Emílio Goeldi, CP 399, CEP 66040-170, Belém, Pará, Brasil.

${ }^{2}$ Instituto Sócio Ambiental e de Recursos Hídricos, Universidade Federal Rural da Amazônia, CP 917, CEP 66077-530, Belém, Pará, Brasil.

${ }^{3}$ Corresponding Author: asrocha@museu-goeldi.br
} 
cies in the Amazon savannas. That is because species identification is difficult or because studies on the herbaceous stratum in general are rare, resulting in significant gaps in our knowledge about the abundance, diversity, and distribution of Poaceae. More efficient utilization of the Poaceae species that are native to the tropics would be feasible if sufficient information on the composition and structure of these resources were more readily available (Coradin 1978). Therefore, identifying which factors are directly involved in determining the diversity of these communities is critical for managing these areas (Camarão \& Souza Filho 1999). In view of these considerations, this study sought to determine the major environmental factors that influence the diversity and distribution of Poaceae in the savannas of the Amazon Estuary. The hypothesis tested is that soil texture and aluminum concentration are the most important factors that influence the abundance and distribution of Poaceae, as has been shown for the savannas in the state of Roraima (Miranda \& Absy 2000; Miranda et al. 2003).

\section{Materials and methods}

\section{Study areas}

We selected seven areas of savanna within the Amazon Estuary, moving from north to south (Fig. 1). Many of these areas appear to be small islands within another type of vegetation. The first five areas are in the state of Pará: Campo da Mangaba (hereafter, Mangaba: $0^{\circ} 45^{\prime} \mathrm{S} ; 47^{\circ} 32^{\prime} \mathrm{W}$ ), located in the municipality of Maracanã and covering 2500 ha; Itapuá $\left(0^{\circ} 49^{\prime} \mathrm{S} ; 48^{\circ} 05^{\prime} \mathrm{W}\right)$, located in the municipality of Vigia Pará (hereafter, Vigia) and covering approximately 1500 ha; and Camará $\left(0^{\circ} 52^{\prime} \mathrm{S}\right.$; $\left.48^{\circ} 35^{\prime} \mathrm{W}\right)$, Joanes $\left(0^{\circ} 50^{\prime} \mathrm{S} ; 48^{\circ} 31^{\prime} \mathrm{W}\right)$, and Deus-me-Ajude $\left(0^{\circ} 46^{\prime} \mathrm{S} ; 48^{\circ} 37^{\prime} \mathrm{W}\right)$, all located in the municipality of Salvaterra, on the island of Marajó, within a patch of approximately 25,000 ha on the southeastern part of the island. The sixth and seventh areas are in the state of Amapá, in the municipalities of Macapá (Santo Antônio Community, $0^{\circ} 02^{\prime} \mathrm{N} ; 51^{\circ} 04^{\prime} \mathrm{W}$ ) and Calçoene (Cunanin Road, $\left.2^{\circ} 30^{\prime} \mathrm{N} ; 51^{\circ} 00^{\prime} \mathrm{W}\right)$, respectively, on the edges of a large patch (approximately 900,000 ha).

The topography of the study area is predominately flat, with smooth undulations in the savannas in northern Amapá. The elevation ranges from 14 to $25 \mathrm{~m}$ above sea level. The climate of the region is an attenuated form of type Awi in the Köppen classification system, characterized by a dry period of three to four months and an average annual temperature of $26^{\circ} \mathrm{C}$ (Moraes et al. 2005). In the 2000-2005 period, the annual precipitation ranged from $2288 \mathrm{~mm}$, in Macapá, to $4781 \mathrm{~mm}$, in Calçoene (Fig. 2).

The rainiest period is between January and May for all of the study areas, except for Maracanã, where the average precipitation levels in January remain low $(90.98 \mathrm{~mm})$. In all of the study areas, the months of September, October, and November are the least rainy, with averages below $50 \mathrm{~mm}$ (Fig. 2). In Calçoene and Itapuá, the average precipitation is above $100 \mathrm{~mm}$ for eight and nine of the year, respectively, whereas the other areas only reach that level for five months

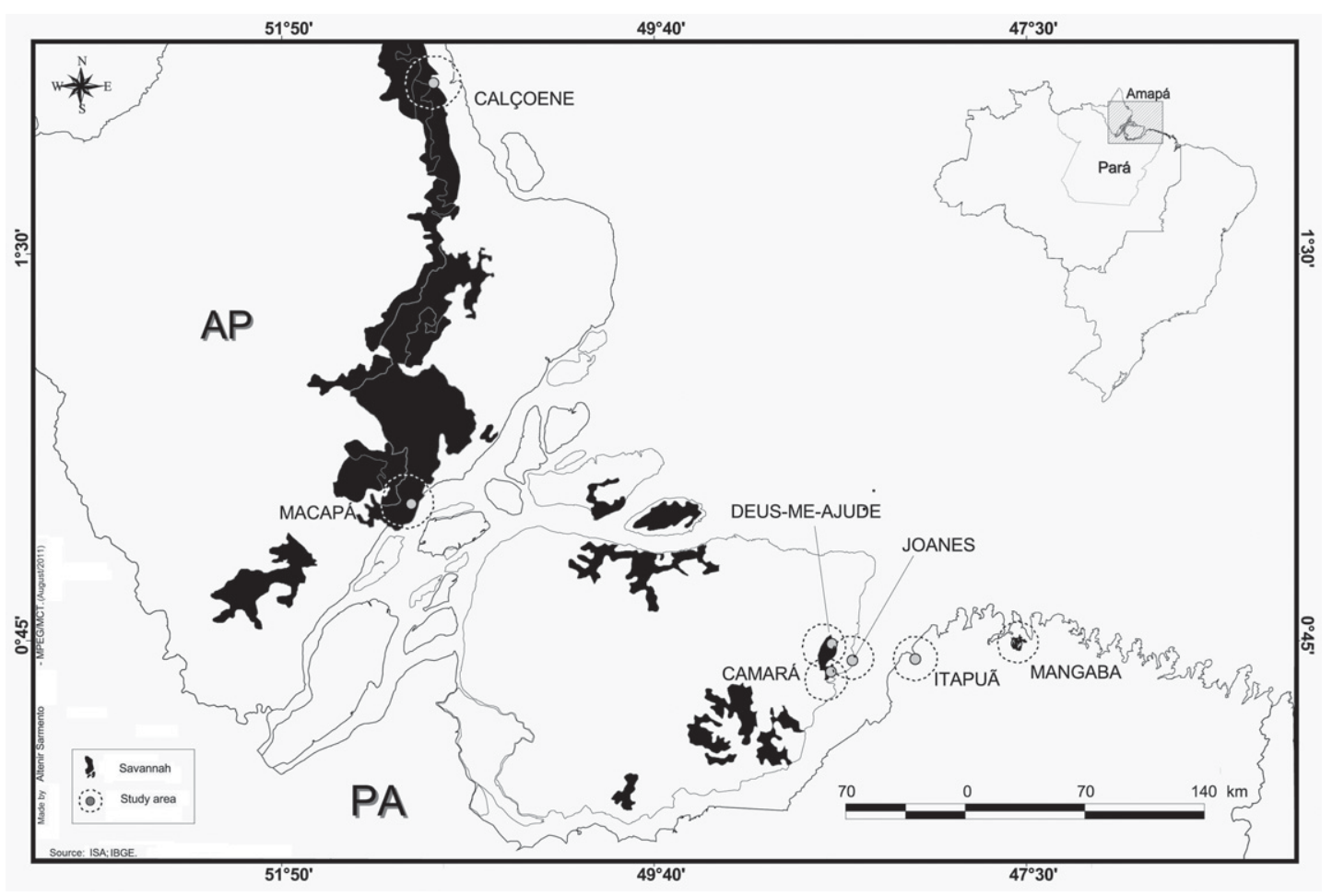

Figure 1. Location of the savannas studied in the Amazon Estuary in Brazil. 

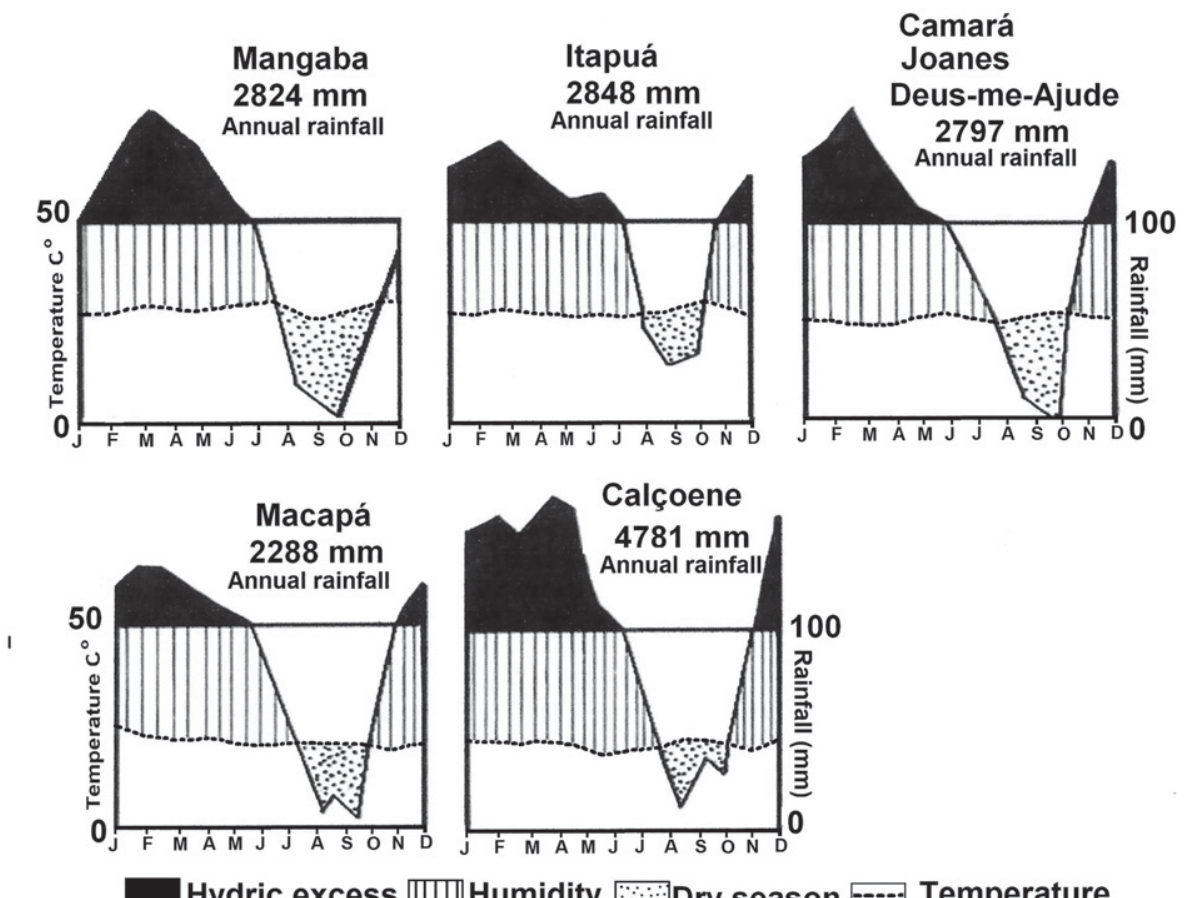

Hydric excess $\mathrm{W}$ Humidity $\ldots$ Dry season $\ldots$ Temperature

Figure 2. Temperature and rainfall in the areas studied, from January 2000 to December 2005.

Source: Brazilian National Meteorological Institute meteorological stations in Salinópolis (Maracanã), Vigia (Itapuá), Soure (Camará, Joanes, and Deus-me-Ajude), Chaves (Macapá) and Calçoene (Amapá).

of the year. The overall seasonal precipitation pattern is similar for all of the areas, the precipitation levels being lowest $(<50 \mathrm{~mm})$ during September, October, and November and highest from December to May (Fig. 2).

The savannas of the Amazon Estuary exhibit a variety of environments such as grasslands, tree savanna, shrub savanna, woodland savanna, and park savanna. The areas studied present a woodland savanna physiognomy (Barbosa \& Miranda 2005) consisting of sparse individual small trees (2-5 $\mathrm{m}$ in height), predominantly sandpaper trees (Curatella americana L), locustberry (Byrsonima spp.), bate-caixa (Salvertia convallariodora St. HM.), Caribbean trumpet trees (Tabebuia caraiba (Mart.) Bur.) and sucuba (Himatanthus articulatus (Vahl) Woodson); individual shrubs measuring 40-60 cm in height; and an herbaceous stratum composed, in large part, of Poaceae and Cyperaceae.

All of the areas showed signs of previous fires. At the time of the inventory, the herbaceous strata had recently recovered from fires that occurred during the preceding dry months. Only one area (Deus-me-Ajude) was partially grazed.

\section{Sampling and analysis methods}

Four plots, each measuring $10 \times 100 \mathrm{~m}$, were marked off in each area (total area, $4000 \mathrm{~m}^{2}$ ). Within each plot, we established 40 subplots, each $1 \mathrm{~m}^{2}$, using a systematic distribution of four subplots every $10 \mathrm{~m}$. The distance between the plots ranged from $500 \mathrm{~m}$ to $1000 \mathrm{~m}$.
In each $1 \mathrm{~m}^{2}$ subplot, the percentage of coverage relative to the total herbaceous stratum was estimated visually with the Braun-Blanquet scale, which is calculated by applying the following formula:

$$
(C R=A i / A) \times 100
$$

where $A i$ is the total area covered by species $i$, and $A$ is the sum of the coverage for all species. All Poaceae species were collected, and their exsiccata were deposited in the herbarium of Museu Paraense Emílio Goeldi (code, MG). The field survey was conducted between May and June 2010, corresponding to the season when the most flowering occurs in the herbaceous stratum. The classification of the subfamilies and tribes followed the examples of the Grass Phylogeny Working Group (GPWG 2001) and the Catalogue of New World Grasses (Zuloaga et al. 2003).

A superficial soil sample $(0-20 \mathrm{~cm}$ depth) consisting of 20 subsamples was collected every $10 \mathrm{~m}$ along the plots. The soil samples were analyzed according to the guidelines established by the Brazilian Agency for Agricultural Research (EMBRAPA 1997). The pipette method was used in order to determine the texture. The $\mathrm{pH}$ was measured using a $\mathrm{pH}$ meter in a 1:2.5 soil-to-water solution. Nitrogen $(\mathrm{N})$ was measured using the Kjeldahl method, and organic matter was measured with the Walkey-Black method. The P, K, and $\mathrm{Na}$ contents were extracted with Melish solution $\left(0.025 \mathrm{~N} \mathrm{H}_{2}\right.$ $\mathrm{SO} 4+0.05 \mathrm{~N} \mathrm{HCl}$ ), measured using a UV-visible spectrophotometer, a flame photometer, and an atomic absorption 
spectrophotometer, respectively. We extracted $\mathrm{Ca}, \mathrm{Mg}$, and $\mathrm{Al}$ using a $1 \mathrm{~N} \mathrm{KCl}$ solution. We measured $\mathrm{Al}$ by acid-base titration using $\mathrm{NaOH}(0.01 \mathrm{~N})$, and we measured $\mathrm{Ca}$ and $\mathrm{Mg}$ with an atomic absorption spectrophotometer.

For structural analysis of the areas, we used the Shannon-Wiener diversity index (Shannon-Wiener 1949, cited in Margurran 1991) and Pielou's evenness index (Pielou 1969, cited in Margurran 1991). To measure the homogeneity of the relative coverage data for the various study areas, we performed a normalized principle component analysis (PCA), using a matrix of seven areas and 24 species. Another normalized PCA was performed to analyze the edaphic variables in the seven areas. All of the relative coverage and soil data were $\log _{(\mathrm{n}+1)}$ transformed.

A co-inertia analysis was performed to facilitate simultaneous interpretation of the PCA results (floristic and edaphic matrices). Co-inertia analysis compares the structures revealed in a PCA to show whether the co-structure described by the major axes is similar to the structures described by the analyses performed for each data matrix (Dolédec \& Chessel 1994). The significance of the multivariate analyses was determined using the Monte Carlo permutation test. The ADE-4 software package (Thioulouse et al. 1997) included in the program R, version 1.9 (R Development Core Team, 2004) was used to perform statistical analyses. In all tests, the level of significance was set at $p \leq 0.05$.

\section{Results}

The Panicoideae subfamily (20 species) accounted for $98.63 \%$ of the total coverage by family, whereas Chloridoideae accounted for $1.2 \%$ and Aristidoideae accounted for $0.1 \%$. In all seven areas, the genera with the highest numbers of species were Axonopus and Paspalum, with five species each (Tab. 1).

Twelve species each accounted for less than $1 \%$ of the total coverage, and ten species collectively accounted for $94.38 \%$ (Tab. 1). The proportional coverage was highest for Trachypogon spicatus (L.f.) Kuntze (33.20\%), Axonopus aureus P. Beauv. (21.46\%), and Axonopus polydactylus (Steud.) Dedecca $(8.63 \%)$, which were also among the tallest species, reaching $1-3 \mathrm{~m}$ in height.

Regarding the herbaceous stratum as a whole (Tab. 1), the coverage of Poaceae per area was highest $(70.38 \%)$ in Camará, followed by Macapá (67.05\%), Joanes (65.67\%), Mangaba (63.04\%), Deus-me-Ajude (62.32\%), Calçoene (58.74\%), and Itapuá (58.51\%).

Calçoene, in the northern part of the state of Amapá, exhibited the highest richness (13 species; 54\%) and the highest Shannon index value $(2,038)$. Mangaba, in northeastern Pará, presented the lowest richness (5 species; $21 \%$ ) and the lowest Shannon index score (831). However, the highest diversity estimates based on Pielou's index were observed in the Macapá and Itapuá savannas (760 and 767, respectively), whereas the estimate was lowest (457) for the Deus-me-Ajude savanna (Tab. 2).
Of the 24 Poaceae species raised, 18 are perennials and six are annuals. The species exhibiting the highest coverage are perennials. Among the annual species, Gymnopogon foliosus (Willd.) Nees, which was recorded only in the savannas located in Pará, showed the highest coverage per area, albeit less than $2 \%$ (Tab. 1).

Only two species (Axonopus aureus and Anthaenantia lanata) occurred in all of the areas (Tab. 1). Axonopus aureus predominated in Itapuá (19.71\%); Axonopus polydactylus predominated in Mangaba (38.47\%); Trachypogon spicatus predominated in Camará (43.46\%), Joanes (38.12\%), Deusme-Ajude (37.29\%), and Macapá (29.13\%); and Paspalum pulchellum predominated in Calçoene (15.47\%).

The first two PCA axes explained 59.01\% of the total variability in the data, the first axis explaining $22.57 \%$ and the second explaining $25.44 \%$. Axis 1 was influenced by the species Trachypogon spicatus, which presented a positive eigenvalue (0.72), and by Mesosetum loliiforme (Hochst. ex Steud.) Chase and Paspalum pulchellum Kunth (Fig. 3), which showed negative eigenvalues $(-0.33$ and -0.39 , respectively). The second axis, in turn, was influenced by the species Axonopus polydactylus and Axonopus aureus (Fig. 3 ) and they exhibited negative eigenvalues ( -0.53 and -0.45 respectively). The Mangaba savanna was floristically and structurally distinct because it shows a high cover percentage of $A$. polydactylus. The Itapuá and Calçoene savannas were grouped because of the predominance of $P$. pulchellum and M. loliiforme coverage. The Camará, Joanes, Deus-meAjude, and Macapá savannas were more similar floristically because of the predominance of T. spicatus, Deus-me-Ajude being slightly separate because of the predominance of Axonopus purpusii. Another observed tendency was that Macapá tended to group with Calçoene and Itapuá because it presented high cover percentages for $M$. loliiforme and $P$. pulchellum. This result shows a clear floristic and structural separation between the stretches of savanna in the Amazon Estuary (Monte Carlo test, $p<0.001$ ).

Soil from the savannas of the Amazon Estuary was generally highly acidic ( $\mathrm{pH} 4.4-5.4)$ and exhibited low nutrient levels. The chemical attributes of the soil were highly variable, and it had a predominantly sandy texture (Tab. 3).

Table 1. Number of species of Poaceae (S), diversity indices of Shannon-Weaver $\left(H^{\prime}\right)$, evenness index (E') for the seven areas of savannahs in the Amazon Estuary.

\begin{tabular}{lccc}
\hline Areas & $\mathrm{S}$ & $\mathrm{H}^{`}$ & $\mathrm{E}^{\prime}$ \\
\hline Mangaba & 5 & 0.831 & 0.516 \\
Itapuá & 10 & 1.767 & 0.767 \\
Camará & 8 & 1.081 & 0.520 \\
Joanes & 8 & 1.070 & 0.515 \\
Deus-me-Ajude & 10 & 1.054 & 0.457 \\
Macapá & 9 & 1.671 & 0.760 \\
Calçoene & 13 & 2.038 & 0.516 \\
\hline
\end{tabular}


Table 2. Physical and chemical variables analysed for soil samples collected from a depth of 0-20 cm in areas of the Amazon Estuary savannahs. MG: Mangaba; IT: Itapuã, CM: Camara, JO: Joanes, DA: Deus-me-Ajude, MC: Macapa, CÇ: Calçoene.

\begin{tabular}{|c|c|c|c|c|c|c|c|}
\hline Fators & MG & IT & $\mathrm{CM}$ & JO & DA & MC & CÇ \\
\hline $\mathrm{pH}\left(\mathrm{H}_{2} \mathrm{O}\right)$ & 5.3 & 5.4 & 5 & 5 & 5 & 4.8 & 4.4 \\
\hline $\mathrm{N}(\%)$ & 0.08 & 0.13 & 0.17 & 0.17 & 0.14 & 0.14 & 0.14 \\
\hline M.O (g.kg-1) & 0.76 & 12.88 & 19.02 & 9.79 & 20.48 & 14.64 & 9.61 \\
\hline P (mg.dm-3) & 1 & 1 & 1 & 1 & 1 & 1 & 1 \\
\hline K (mg.dm-3) & 19 & 19 & 13 & 10 & 13 & 21 & 19 \\
\hline $\mathrm{Na}(\mathrm{mg} \cdot \mathrm{dm}-3)$ & 11 & 8 & 6 & 6 & 6 & 12 & 10 \\
\hline $\mathrm{Ca}(\mathrm{cmolc} \cdot \mathrm{dm}-3)$ & 0.3 & 0.4 & 0.4 & 0.4 & 0.4 & 0.3 & 0.2 \\
\hline $\mathrm{Ca}+\mathrm{Mg}(\mathrm{cmolc} \cdot \mathrm{dm}-3)$ & 0.6 & 0.6 & 0.7 & 0.6 & 0.5 & 0.5 & 0.5 \\
\hline $\mathrm{Al}$ (cmolc.dm-3) & 0.4 & 0.8 & 1.2 & 0.8 & 1.3 & 1 & 1.2 \\
\hline $\mathrm{H}+\mathrm{Al}(\mathrm{cmolc} . \mathrm{dm}-3)$ & 2.97 & 3.3 & 6.44 & 3.3 & 6.27 & 5.28 & 4.79 \\
\hline Coarse sand $(\mathrm{g} / \mathrm{kg})$ & 590 & 477 & 393 & 440 & 426 & 168 & 146 \\
\hline Fine sand (g/kg) & 283 & 204 & 328 & 309 & 344 & 455 & 350 \\
\hline Silt (g/kg) & 68 & 239 & 99 & 131 & 111 & 178 & 405 \\
\hline Clay (g/kg) & 60 & 80 & 180 & 120 & 120 & 200 & 100 \\
\hline
\end{tabular}

The PCA of the soil showed that the first two axes explained $83.65 \%$ of the variance in the data, the first axis explaining $57.05 \%$ and the second explaining $26.60 \%$ (Fig. 4). Axis 1 was influenced by organic matter, showing a positive eigenvalue (0.33) for coarse sand and a negative eigenvalue $(-0.0780)$ for organic matter. Axis 2 was influenced by silt, which presented a positive eigenvalue (0.60), and coarse sand, which presented a negative eigenvalue $(-0.54)$ (Monte Carlo test, $p<0.001$ ).

The ordination diagram (Fig. 4) shows that the soil gradient presented high silt contents in the Calçoene and Macapá savannas (upper left), high organic matter contents in the Camará and Deus-me-Ajude savannas (lower left), and high coarse sand content in the Mangaba savanna (opposite side). The other areas (Joanes and Itapuá) are relatively close to the center of the diagram, indicating a low correlation with the edaphic factors studied. The cluster of areas on the left side of the diagram showed high levels of organic matter, which was the variable most strongly correlated with the first axis and the factor that most influenced Poaceae distribution in the savannas evaluated.

The co-inertia analysis showed a significant correlation between the floristic and edaphic matrices (Monte Carlo test, $p<0.001)$. The first two axes explained $95 \%$ of the variance in the data (Fig. 5). Axis 1, which explained 59\% of the variability in the data, generated an ordination in which the areas with high levels of organic matter (Deus-me-Ajude and Camará) were clustered in the lower left, and the area with the highest coarse sand content (Mangaba) was on the opposite side. Axis 2, which was influenced by the silt content of the soil, explained $36 \%$ of the variability in the data, showing a positive correlation with areas with higher silt content (Itapuá, Macapá and Calçoene), at the top of the diagram, and a negative correlation with areas with lower silt content (Mangaba, Camará, Joanes and Deus-me-Ajude), at the bottom.

Trachypogon spicatus correlated with areas of high organic matter content; Mesosetum loliiforme and Paspalum pulchellum correlated with areas of higher silt content; and Axonopus polydactylus correlated mainly with sandy areas. These patterns were the same as those yielded by the PCA.

\section{Discussion}

It has been shown that the duration of the seasons and the amount of rainfall can influence the vegetation in the savannas of central Brazil (Goedert et al. 2008). In the present study, however, the difference in total annual rainfall between the areas sampled did not influence the distribution of Poaceae. The areas that presented similar rainfall features, such as Mangaba, Camará, Joanes, and Deus-me-Ajude, presented very distinct edaphic and floristic characteristics, whereas Macapá, Itapuá, and Calçoene, which are more floristically and edaphically similar to each other, exhibit different annual precipitation totals.

The results indicate that soil texture is the most important factor determining the Poaceae structure in the savannas of the Amazon Estuary. These results are in partial agreement with those reported by Miranda \& Absy (2000), who showed that soil texture and aluminum levels determine savanna physiognomy in the state of Roraima and differ from those found in the savannas of central Brazil, where chemical factors ( $\mathrm{pH}$ and aluminum) are the best predictors of species density in herbaceous communities (Amorim \& Batalha 2008). 


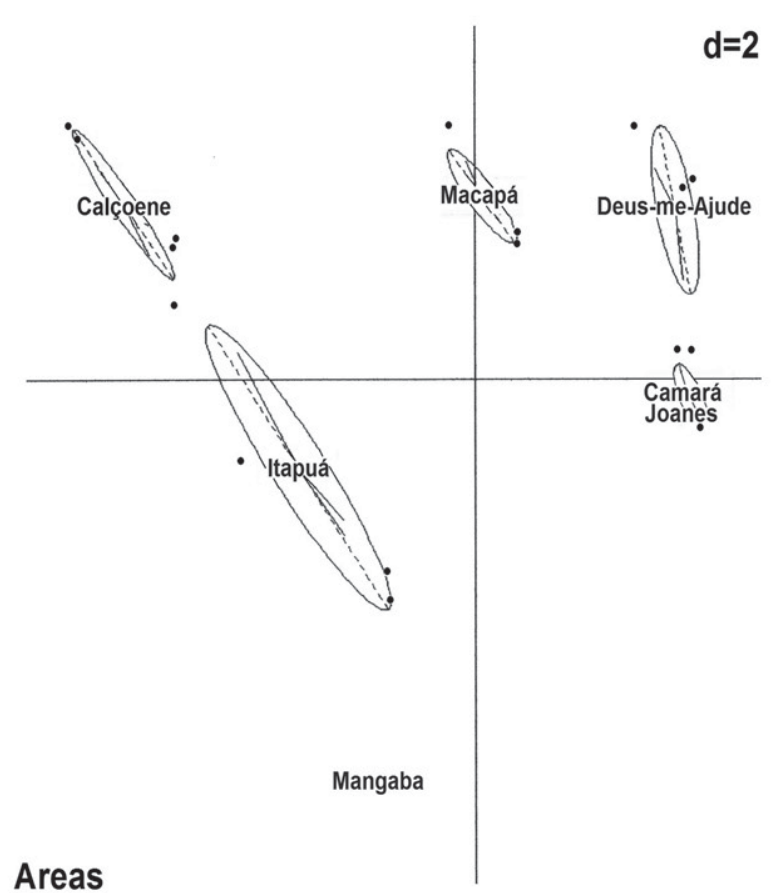

Areas

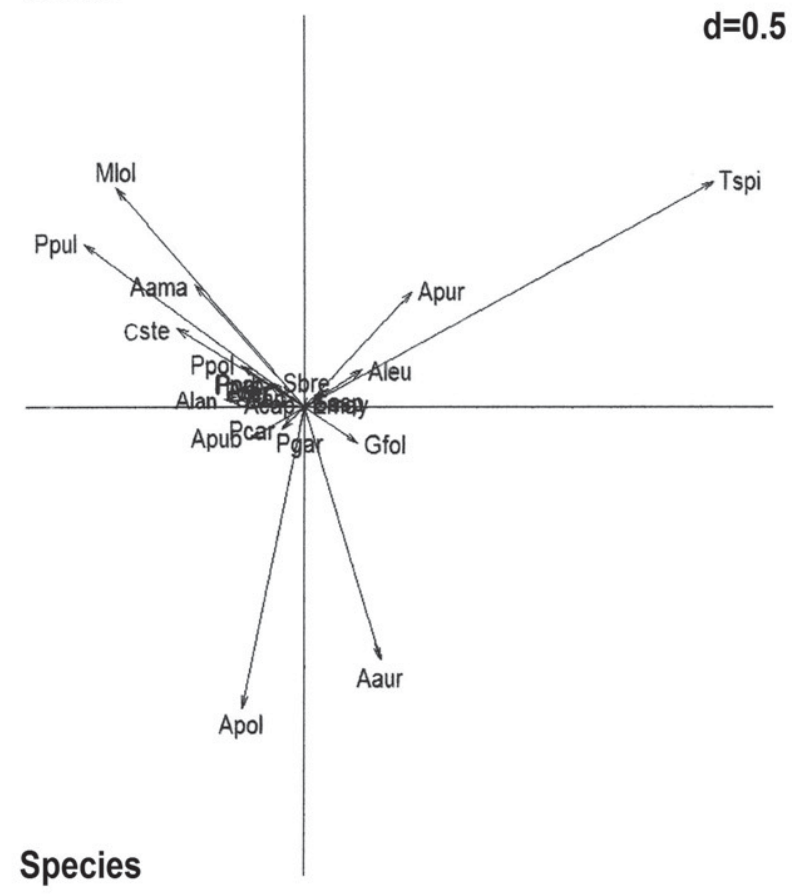

Figure 3. Principle component analysis ordination of seven savannas in the Amazon Estuary in Brazil, based on 24 Poaceae species. A: Ordination diagram for the Poaceae species sampled here as a function of the areas studied: Deusme-Ajude, Camará, Calçoene, Joanes, Macapá, Mangaba, and Itapuá. B: Graph of the Poaceae species. (Aleu: Andropogon leucosthachyus, Alan: Anthaenantia lanata, Aama: Axonopus amapaensis, Aaur: Axonopus aureus, Apol: Axonopus polydactylus, Apub: Axonopus pubivaginatus, Apur: Axonopus purpusii, Cste: Coleataenia stenodes, Mlol: Mesosetum loliiforme, Pcar: Paspalum carinatum, Pgar: Paspalum gardnerianum, Pmul: Paspalum multicaule, Ppar: Paspalum parviflorum, Ppul: Paspalum pulchellum, Sbre: Schizachyrium brevivolium, Ssan: Schizachyrium sanguineum, Sasp: Streptostachys asperifolia, Tspi: Trachypogon spicatus, Tner: Trichanthecium nervosum, Tpol: Trichanthecium polycomum, Acap: Aristida capillacea, Ator: Aristida torta, Emay: Eragrostis maypurensis, Gfol: Gymnopogon foliosus). d, Statistical significance of the clusters by the Monte Carlo permutation test.
The soil in the savannas studied exhibited higher clay levels in the middle and lower sections at the northern and southern edges. Clay particles promote greater stability of organic substrates, directly influencing organic matter accumulation in the soil (Coleman et al. 1989). Similarly, higher coarse sand contents contribute to better drainage and, consequently, lower clay contents (Guimarães et al. 2002). Four species correlated with the different environments: Trachypogon spicatus was correlated with soils with more organic matter; Axonopus polydactylus was correlated with soils with a greater sand content; and Paspalum pulchellum and Mesosetum loliiforme were correlated with soils with greater silt content. Although there are many factors that limit the occurrence of the Poaceae in the savannas of the Americas (Allem \& Valls 1987), low fertility was the only one of those factors observed in the savannas of the Amazon Estuary in the present study, corroborating the results obtained by Baruch et al. (1985), Baruch \& Gómez (1996), and Baruch (2005).

Among the seven areas studied, Trachypogon spicatus predominated in the Camará, Joanes, Deus-me-Ajude, and Macapá savannas, where the organic matter and clay contents were highest. This species was not found in the Mangaba and Itapuá savannas, which were areas with low organic matter and clay contents, as well as high coarse sand contents. Although this species is very important in tropical savannas and dominates the herbaceous stratum across large areas (López-Olmedo et al. 2006; Ramirez et al. 2007), it is subjected to nutritional limitations, leading to the production of smaller plants in populations where the soil is less fertile (Baruch 2005).

Soil with low water and nutrient availability is occupied by species with low nutritional requirements (Medina \& Huber 1992). The Mangaba savanna exhibited the highest coarse sand content and the lowest clay content, potentially influencing water and nutrient availability (Barros et al. 2009) and, consequently, the predominance of Axonopus polydactylus (38.47\%), a species common to coastal woodlands (Cialdella et al. 2006), where the soil is low in clay and organic matter, with low water and nutrient retention capacity (Cuzzuol \& Campos 2001). This may be one of the few savanna areas in the Amazon, if not the only area, where two Axonopus species dominate the herbaceous stratum (Takeuchi 1960; Coradin 1978; Bastos 1984; Allem \& Valls 1987; Miranda \& Carneiro 1994; Miranda \& Absy 2000; Baruch 2005; Magnusson et al. 2008; Viana \& Filgueiras 2008).

The low fertility of estuarine savannas might reflect the environmental conditions to which ecosystems have been subject in the past (Miranda 2010), and the intense anthropogenic activities have impacts that might be reducing the wealth of already fragile environments, such as the Mangaba savanna, the most disturbed and poorest in species of the savannas studied. The Itapuá, Macapá, and Calçoene savannas exhibited the highest soil contents of silt, which is a factor that diminishes soil permeability (Resende et al. 
Table 3. Relative cover (\%) of the 24 identified Poaceae species, abbreviations used in the PCA, collected records (Voucher, MG herbarium), cycle and percentage of relative coverage per area. MG: Mangaba; IT: Itapuã; CM: Camara, JO: Joanes, DA: Deus-me-Ajude, MC : Macapa, CÇ: Calçoene.

\begin{tabular}{|c|c|c|c|c|c|c|c|c|c|c|}
\hline Species & $A B$ & $V C$ & $C I$ & MG & $I T$ & $C M$ & JO & $D A$ & $M C$ & $C C ̧$ \\
\hline \multicolumn{11}{|l|}{ Panicoideae } \\
\hline Anthaenantia lanata (Kunth) Benth & Alan & Rocha 1151 & Perene & 2.2 & 3.8 & 2.4 & 2.6 & 0.8 & 4.7 & 7.6 \\
\hline Andropogon leucosthachyus Kunth & Aleu & Rocha 1051 & Perene & - & - & 2.9 & 1.0 & 0.2 & 2.1 & - \\
\hline Axonopus amapaensis G.A. Black & Aama & Rocha 1136 & Perene & - & - & - & - & - & 4.9 & 5.1 \\
\hline A. aureus P.Beauv. & Aaur & Rocha 1050 & Perene & 21.8 & 19.7 & 18.4 & 20.8 & 3.3 & 9.1 & 2.4 \\
\hline A. polydactylus (Steud.) Dedecca & Apol & Rocha 1063 & Perene & 38.5 & - & - & - & - & - & - \\
\hline A. pubivaginatus Henrard. & Apub & Rocha 1207 & Perene & - & 12.6 & 0.8 & 0.2 & - & - & - \\
\hline A. purpusii (Mez) Chase & Apur & Rocha 1245 & Perene & - & 0.5 & 0.3 & 0.6 & 18.5 & - & - \\
\hline Coleataenia stenodes (Griseb.) Soreng & Cste & Rocha 1323 & Perene & - & 0.2 & - & - & - & - & 8.4 \\
\hline Mesosetum loliiforme (Hochst.ex Steud.) Chase & Mlol & Rocha 1114 & Perene & - & 5.4 & - & - & 1.3 & 10.2 & 12.1 \\
\hline Trichanthecium nervosum Lam. & Pner & Rocha 1116 & Perene & - & - & - & - & - & - & 0.6 \\
\hline T. polycomum Trin. & Ppol & Rocha 1337 & Anual & - & - & - & - & - & - & 3.2 \\
\hline Paspalum carinatum Humb.\&Bonpl. ex Flûggé & Pcar & Rocha 1252 & Perene & - & 2.8 & - & - & - & - & - \\
\hline P. gardnerianum Nees & Pgar & Rocha 1057 & Perene & 0.3 & 0.9 & - & 0.6 & 0.2 & 0.05 & - \\
\hline P. multicaule Poir. & Pmul & Rocha 1223 & Anual & - & - & - & - & - & - & 1.2 \\
\hline P. parviflorum Rhode ex Flûggé & Ppar & Rocha 1121 & Anual & - & - & - & - & - & - & 1.2 \\
\hline P. pulchellum Kunth & Ppul & Rocha 1205 & Perene & - & 11.3 & - & - & - & 6.4 & 15.5 \\
\hline Schizachyrium brevifolium (Sw.) Nees ex Bûse & Sbre & Rocha 1410 & Anual & - & - & - & - & - & 0.5 & - \\
\hline S. sanguineum (Rets.) Alst. & Ssan & Rocha 1120 & Perene & - & - & 0.2 & - & - & - & 0.9 \\
\hline Streptostachys asperifolia Desv. & Sasp & Rocha 1304 & Perene & - & - & - & - & 0.12 & - & - \\
\hline Trachypogon spicatus (L.f.) Kuntze & Tspi & Rocha 1124 & Perene & - & - & 43.5 & 38.1 & 37.3 & 29.1 & - \\
\hline \multicolumn{11}{|l|}{ Aristidoideae } \\
\hline Aristida capillacea Lam. & Acap & Rocha 1382 & Anual & - & - & - & - & - & - & 0.02 \\
\hline A. torta (Nees) Kunth & Ator & Rocha 1119 & Perene & - & - & - & - & - & - & 0.6 \\
\hline \multicolumn{11}{|l|}{ Chloridoideae } \\
\hline Eragrostis maypurensis (Kunth) Steud. & Emay & Rocha 1166 & Perene & - & - & - & - & 0.02 & - & - \\
\hline \multirow[t]{2}{*}{ Gymnopogon foliosus (Willd.) Nees } & Gfol & Rocha 1152 & Anual & 0.2 & 1.2 & 1.8 & 1.7 & 0.5 & - & - \\
\hline & Total & & & 63.0 & 58.5 & 70.4 & 65.7 & 62.3 & 67.0 & 58.7 \\
\hline
\end{tabular}

2002). The lower permeability might have influenced the levels of Poaceae diversity and richness. Paspalum pulchellum, Mesosetum loliiforme, and Coleataenia stenodes, species typically found in humid areas (Rocha \& Lins 2009), stand out among the dominant species in these savannas.

These data differ from the results obtained by Araujo et al. (2002) in the state of Minas Gerais and by Pinder \& Rosso (1998) in the Pantanal Biome, where higher species richness coincided with higher permeability. However, the data corroborate the findings of Munhoz \& Felfili (2006) in humid savanna areas in the Federal District of Brasília, where Poaceae shows a high level of richness.

The ecological indices estimated for the Itapuá, Macapá, and Calçoene savannas suggest some uniformity of Poaceae coverage, with three or four species dominating the herbaceous stratum, whereas in areas with higher permeability (Mangaba, Camará, Joanes, and Deus-me-Ajude), only two species dominated the herbaceous stratum. This dominance by a few species influenced the low Shannon diversity results.

The coverage of the five species from the genus Axonopus (A. amapaensis, A. aureus, A polydactylus, A. pubivaginatus, and $A$ purpusii) decreased from north to south, with values of $60.32 \%$ in Mangaba, $32.76 \%$ in Itapuá, $19.51 \%$ in Camará, $21.63 \%$ in Joanes, $21.83 \%$ in Deus-me-Ajude, $14.04 \%$ in Macapá, and $7.5 \%$ in Calçoene. This gradient correlated positively with coarse sand content, whereas it correlated negatively with clay and organic matter contents. Axonopus was the genus that was most sensitive to changes in relation to the edaphic factors studied. Axonopus aureus, the only species of the genus occurring in all of the areas, showed the same tendency as the genus as a whole, presenting a higher coverage index in areas with higher coarse sand contents. 


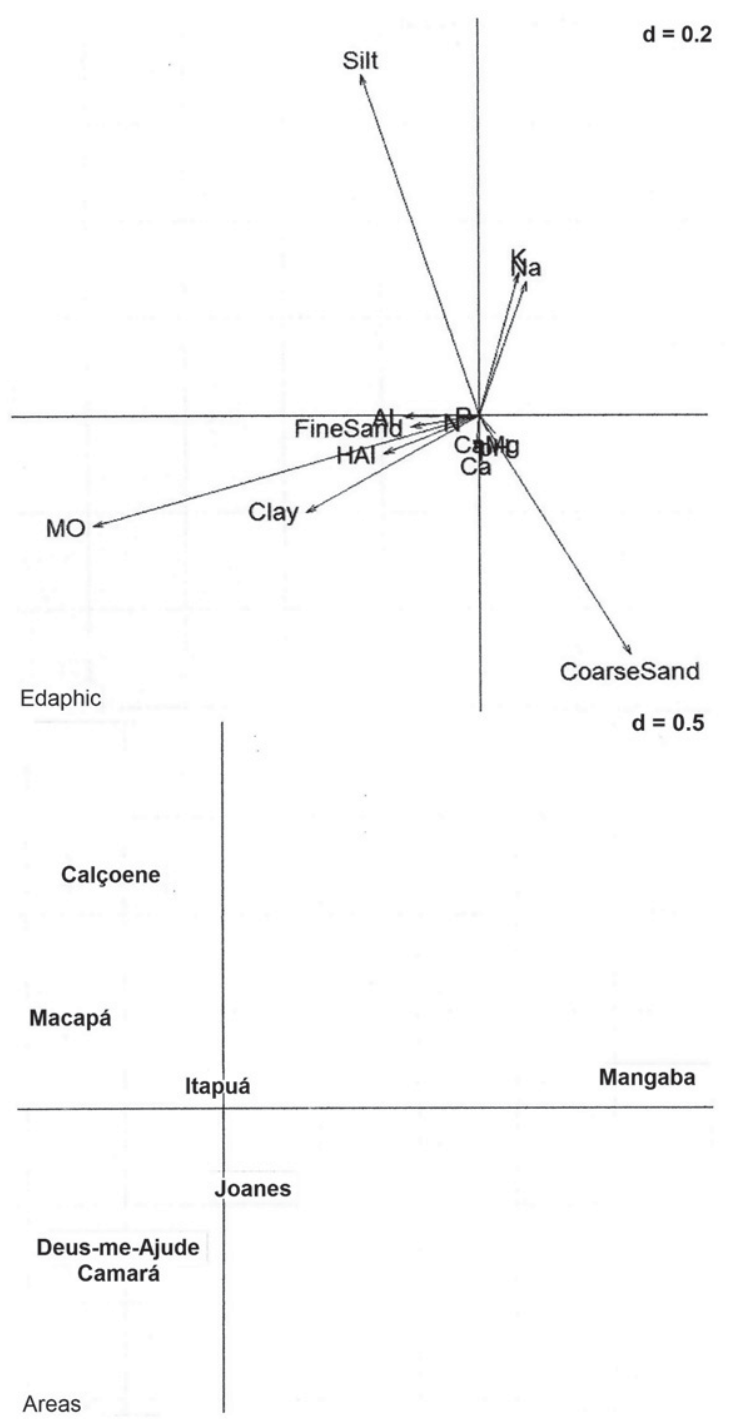

Figure 4. Principle component analysis ordination of seven savannas in the Amazon Estuary in Brazil, based on 15 soil variables. A: Graph of the edaphic variables (fine sand, coarse sand, clay, silt, $\mathrm{pH}$, elements, and organic matter). B: Ordination diagram for the edaphic factors as a function of the areas studied: Deus-me-Ajude, Camará, Calçoene, Joanes, Macapá, Mangaba, and Itapuá. $\mathrm{Al}$ - aluminum; $\mathrm{pH}$ - $\mathrm{pH}$ in water; $\mathrm{N}$ - nitrogen; $\mathrm{P}$ - phosphorus; $\mathrm{K}$ - potassium; $\mathrm{Na}$ - sodium; $\mathrm{Ca}$ - calcium; $\mathrm{Mg}$ - magnesium; $\mathrm{H}+\mathrm{Al}$ - hydrogen + aluminum; $\mathrm{OM}$ - organic matter.

d, Statistical significance of the clusters by the Monte Carlo permutation test.

Four endemic taxa were found: Axonopus polydactylus, a species endemic to northern and northeastern Brazil (Cialdella et al. 2006) and recorded only in Mangaba; Axonopus pubivaginatus var. tomentosus, which is endemic to the Vigia savanna (Black 1963) and was recorded only in Itapuá, in the municipality of Vigia; A. pubivaginatus var. limae, which is endemic to the Marajó and Amapá savannas (Black 1963) and was recorded only in Camará and Joanes; and A. amapaensis, which is endemic to the Amapá savannas (Black 1963) and was recorded only in Macapá and Calçoene.

The low endemism is expected of areas with recent geological formation, such as the savannas studied, dating back to Holocene (Miranda 2010), whether in relation to the flora, as noted by De Granville (1982), or birds, as noted by Henriques \& Oren (1997). However, it will be welcome a biogeographic study involving cladistic analyses of Axonopus to understand the possible speciation processes of the group, may result in discoveries of new taxa of the genus.

Although the soil gradient influenced the Poaceae coverage at the species and genus levels, the total percentage changed very little at the family level, even in the partially grazed area (Deus-me-Ajude), Poaceae accounting for an average of $63.67 \%$ of the total herbaceous stratum.

The percentage covered by Poaceae observed in the present study was greater than was found previously in western Pará (Magnusson et al. 2008), where eight species of Poaceae were identified, with only two of them dominant (Paspalum carinatum and Trachypogon spicatus), although the total coverage of the family was $40.06 \%$. In the savannas within the state of Roraima, Poaceae comprised only $19 \%$ of the herbaceous stratum in a survey performed by Takeuchi (1960) and $43.40 \%$ in a study conducted by Miranda \& Absy (1997). The dominance of Poaceae might be related to the homogeneity of the nutritional aspects of the soil over time.

Of the 24 species identified, 22 are also found in the savannas of Roraima (Coradin 1978; Miranda \& Absy 2000). Of the 24 species identified in the savannas evaluated in the present study, 11 have a Neotropical distribution (Andropogon leucostachyus, Aristida capillacea, Aristida torta, Axonopus aureus, A. purpusii, Eragrostis maypurensis, Anthaenantia lanata, Coleataenia stenodes, Paspalum multicaule, P. pulchellum, and Trachypogon spicatus); five are restricted to South America (Axonopus pubivaginatus, Gymnopogon foliosus, Trichanthecium nervosum, Trichanthecium polycomum, and Paspalum gardnerianum); four occur in South America and extend to the Caribbean (Mesosetum loliiforme, Paspalum carinatum, Paspalum parviflorum, and Streptostachys asperifolia); one is endemic to the Amapá savannas (Axonopus amapaensis); one is restricted to northern and northeastern Brazil (Axonopus polydactylus); and two are pantropical (Schizachyrium brevifolium and $S$. sanguineum) (Türpe 1984). The floristic composition in the areas is dominated by widely distributed Neotropical species, with a strong influence from the Roraima savannas.

In Brazil, savannas are the ecosystems in which invasive exotic Poaceae species create the greatest problems (Pivello et al. 1999). However, no such problems were observed in the savannas studied, to which all of the species identified are native.

Because of the recent isolation of the Amazon savannas, differentiation and formation of new plant associations are occurring in these areas (De Granville 1982; Miranda \& Carneiro-Filho 1994). The floristic and structural traits of the savannas studied here suggest that the Poaceae communities, which are common in the American tropics, exhibit low diversity and a unique distribution pattern in which a homogeneous physiognomy of a group of species predomi- 


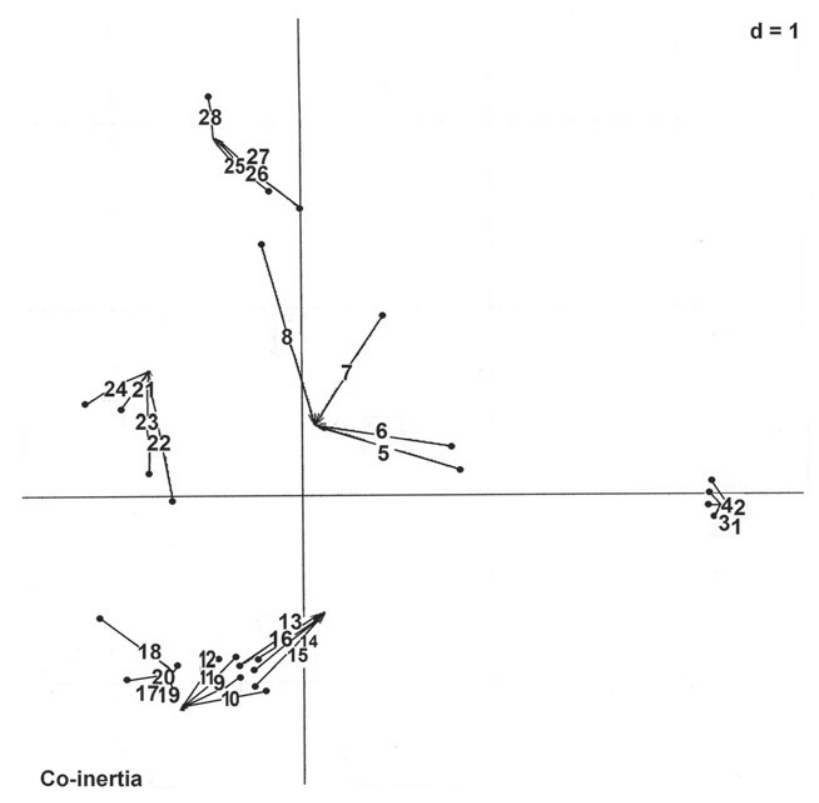

Figure 5. Co-inertia ordination of the Poaceae species distribution versus edaphic factors. Diagram showing the position of the 28 plots on the two axes of ordination. Plots 1-4 were in Mangaba, plots 5-8 were in Itapuá, plots 9-12 were in Camará, plots 13-16 were in Joanes, plots 17-20 were in Deus-me-Ajude, plots 21-24 were in Macapá, and plots 25-28 were in Calçoene.

d, Statistical significance by the Monte Carlo permutation test. The edges of lines indicate the plot positions in the two initial ordinations (principle component analyses of species distribution and edaphic factors), the length of the line indicates how the plots were different.

nates in each section. The data presented here suggest that the abundance and distribution of Poaceae are related to a gradient of soil factors, among which the organic matter, coarse sand, and silt contents were the most important. These data are useful for understanding the plant-soil interactions in this environment, which could promote strategies for conservation, management, and revegetation.

\section{Acknowledgments}

We thank Salustiano Vilar C. Neto for assisting with the field work, Tâmara Thais Lima for helping perform the statistical analysis, Conselho Nacional de Desenvolvimento Científico e Tecnológico - CNPq (Proc. 486145/2013-1) and to Dr. Élder Antônio S. Paiva for his kind and helpful advice in the manuscript.

\section{References}

Ab'Sáber, A.N. 2002. Bases para o estudo dos ecossistemas da Amazônia brasileira. Estudos Avançados 45: 7-30.

Allem, A.C. \& Valls, J.F.M. 1987. Recursos forrageiros nativos do Pantanal Mato-Grossense. Brasília: EMBRAPA-CENARGEN, 339. Documentos, 8 .

Alves, R.N.B., Alves, R.M.M. \& Mochiutti, S. 1992. Diagnóstico da agropecuária amapaense. Macapá: Embrapa Amapá (Documento. 3).
Amorim, P.K. \& Batalha, M.A. 2008. Soil chemical factors and grassland species density in Emas National Park (central Brazil). Brazilian Journal of Biology 68: 279-285.

Araújo, G.M., Barbosa, A.A.A., Arantes, A.A. \& Amaral, A.F. 2002. Composição florística de veredas no Município de Uberlândia, MG. Revista Brasileira de Botânica 25: 475-493.

Barbosa, R.I. \& Miranda, I.S. 2005. Fitofisionomias e diversidade vegetal nas savanas de Roraima. Pp. 61-78 In: Barbosa R.I, Xaud H.A.M. and Souza J.M.C. (org.). Savanas de Roraima: etnoecologia, biodiversidade e potencialidades agrossilvipastoris. Boa Vista, FEMACT.

Barros, L.S., Vale Jr, J.F., Schaefer, C.E.G.R. \& Mourão Júnior, M. 2009. Perdas de solo e água em plantio de Acacia mangium wild e savana em Roraima, norte da Amazônia. Revista Brasileira de Ciência do Solo 33: 447-454.

Baruch, Z. 2005. Trachypogon plumosus (Poaceae), un caso de alta diversidad interpoblacional en sabanas neotropicales. Interciencia 30: 488-494.

Baruch, Z. \& Gómez, J.A. 1996. Dynamics of energy and nutrient concentration and construction cost in a native and two alien $\mathrm{C} 4$ grasses from two Neotropical savannas. Plant and Soil 181: 175-184.

Baruch, Z., Ludlow, M.M. \& Davis, R. 1985. Photosynthetic responses of native and introduced C4 grasses from Venezuelan savannas. Oecologia 67: 288-293.

Bastos, M.N.C. 1984. Levantamento florístico dos campos do Estado do Pará. I - Campos de Joanes (Ilha de Marajó). Boletim do Museu Paranese Emílio Goeldi, série botânica, 1(1/2): 67-86.

Beard, J.S. 1953. The Savanna Vegetation of Northern Tropical America. Ecological Monographs 23: 149-215.

Black, G.A. 1963. Grasses of the genus Axonopus. Advancing Frontiers of Plant Science 5: 1-186.

Camarão, A.P. \& Souza Filho, A.P. 1999. Pastagens nativas da Amazônia. Belém, Embrapa Amazônia Oriental.

Castro, A.A.J., Martins, F.R., Tamashiro, J.Y. \& Shepherd, G.J. 1999. How rich is the flora of Brazilian cerrados? Annals of the Missouri Botanical Garden 86: 192-224.

Cialdella, A.M., Morrone, O. \& Zuloaga, F.O. 2006. Revisión de las especies de Axonopus (Poaceae, Panicoideae, Paniceae), serie Suffulti. Annals of the Missouri Botanical Garden 93: 592-633.

Coleman, D.C., Oades, J.M., Uehara, G. 1989. Dynamics of soil organic matter in tropical ecosystems. Honolulu : University of Hawaii Press.

Coradin, L. 1978. The grasses of the natural savannas of the Federal Territory of Roraima, Brazil. PhD Thesis, University of New York Botanical Garden, Nova York.

Cuzzuol, G.R.F. \& Campos, A. 2001. Aspectos nutricionais na vegetação de manguezal do estuário do rio Mucuri, Bahia, Brasil. Revista Brasileira de Botânica 24: 227-234.

De Granville J.J. 1982. Rain forest and xeric flora refuges in French Guiana. Pp. 159-181. In: Prance G.T.(ed.). Biological diversification in the tropics. New York, Columbia University Press.

Dolédec, S., \& D. Chessel. 1994. Co-inertia analysis: an alternative method for studying species-environment relationships. Freshwater Biology 31:277-294.

EMBRAPA. 1997. Manual de métodos de análises de solo. 2.ed. Rio de Janeiro, Ministério da Agricultura e do Abastecimento, 212p.

Goedert, W.J.; Wagner, E.; Barcellos, A.O. Savanas Tropicais: dimensão, histórico e perspectivas. In: Faleiro, F.G.; Neto, A.L.F. (Eds.). Savanas: desafios e estratégias para o equilíbrio entre sociedade, agronegócio e recursos naturais. Planaltina, DF: Embrapa Cerrados, 2008. p. 49-80.

GPWG - GRASS PHYLOGENY WORKING GROUP. 2001. Phylogeny and subfamilial classification of grasses (Poaceae). Annals of the Missouri Botanical Garden 88: 373-457.

Guimarães, A. J. M.; Araújo, G. M.; Corrêa, G. F. C. 2002. Estrutura fitossosiológica em área natural e antropizada de uma vereda em Uberlândia, MG. Acta Botanica Brasilica 16: 317-329.

Henriques, L.M.P. \& Oren, D.C. 1997. The avifauna of Marajó, Caviana and Mexiana islands, Amazon river estuary, Brazil. Revista Brasileira de Biologia 57: 357-382.

López-Olmedo,L.I., Pérez-García, E.A. \& Meave, J.A. 2006. Estructura y composición florística de las sabanas de la región de Nizanda, Istmo de Te Huantepec (Oaxaca), México. Acta Botanica Mexicana 77: 41-67. 
Magnusson, W.E., Lima, A.P., Albernaz, A.L.K.M., Sanaiotti, T.M. \& Guillaumet, J. 2008. Composição florística e cobertura vegetal das savanas na região de Alter do Chão, Santarém - PA. Revista Brasileira de Botanica 31: 165-177.

Margurran, A.E. 1991. Ecological diversity and its measurement. Princeton, Princeton University Press.

Medina, E. \& Huber, O. 1992. The role of biodiversity in the functioning of savanna ecosystems. Pp. 139-158. In: Walker B.H. (ed.). Determinants of tropical savannas. Oxford, IRL Press.

Miranda, M.C.C. 2010. Sedimentologia, isótopos estáveis e palinologia de depósitos quaternários no leste da Ilha de Marajó, estado do Pará. $\mathrm{PhD}$ Thesis, University of São Paulo.

Miranda, I.S. \& Absy, M.L. 1997. Flora fanerogâmica das savanas de Roraima. Pp. 445-462. In: Barbosa R.I., Ferreira E. \& Castellón E.(eds.). Homem, ambiente e ecologia no Estado de Roraima. Manaus, INPA.

Miranda, I.S. \& Absy, M.L. 2000. Fisionomias das Savanas de Roraima, Brasil. Acta Amazonica 30: 423-440.

Miranda, I.S., Absy, M.L. \& Rebelo, G.H. 2003. Community Structure of Woody Plants of Roraima Savannahs, Brazil. Plant Ecology 164: $109-123$.

Miranda, I.S. \& Carneiro Filho, A. 1994. Similaridade florística de algumas de algumas savanas amazônicas. Boletim do Museu Paraense Emílio Goeldi, série Botanica 10: 249-267.

Moraes, B.C., Costa, J.M.N., Costa, A.C.L. \& Costa, M.H. 2005. Variação espacial e temporal da precipitação no Estado do Pará. Acta Amazonica 35: 207-214.

Munhoz, C.B.R. \& Felfili, J.M. 2006. Fitossociologia do estrato herbáceosubarbustivo de uma área de campo sujo no Distrito Federal, Brasil. Acta Botanica Brasilica 20: 671-685.

Pinder, L. \& Rosso, S. 1998. Classification and ordination of plant formations in the Pantanal of Brazil. Plant Ecology 136: 151-165.

Pivello, V.R., Carvalho, V.M.C., Lopes, P.F., Peccinini, A.A. \& Rosso, S. 1999. Abundance and distribution of native alien grasses in a "Cerrado”. (Brazilian Savanna) Biological Reserve. Biotropica 31: 71-82.
Ramirez, N., Dezzeo, N. \& Chacón, N. 2007. Floristic composition, plant species abundance, and soil properties of montane savannas in the Gran Sabana, Venezuela. Flora 202: 316-327.

Ratter, J.A., Bridgewater, S., Atkinson, R. \& Ribeiro, J.F. 1996. Analysis of the floristic composition of the Brazilian cerrado vegetation II: comparison of the woody vegetation of 98 areas. Edinburgh Journal of Botany 53: 153-180.

Resende, M.; Curi, N.; Rezende, S.B. \& Corrêa, S.A. 2002. Pedologia: Base para distinção de ambientes. 4th edn. Viçosa, NEPUT.

Rocha, A.E.S. \& Lins, A.L.F.A. 2009. Checklist das Poaceae de áreas inundáveis e inundadas do nordeste do estado do Pará. Acta amazonica 39: 763-772.

Rossetti, D.F., Almeida, S., Amaral, D.D., Lima, C.M. \& Pessenda, L.C.R. 2010. Coexistence of forest and savanna in an Amazonian area from a geological perspective. Journal of Vegetation Science 21: 120-132.

Ruggiero, P.G.C., Batalha, M.A., Pivello, V.R. \& Meirelles, S.T. 2002. Vegetation-soil relationships in cerrado (Brazilian savanna) and semideciduous forest, Southeastern Brazil. Plant Ecology 160: 1-16.

Takeuchi, M. 1960. A estrutura da vegetação na Amazônia. II. As savanas do norte da Amazônia. Boletim do Museu Paraense Emílio Goeldi 7: 1-14.

Thioulouse, J., D. Chessel, S. Dolédec, and J. M. Olivier. (1997) ADE-4: a multivariate analysis and graphical display software. Statistics and Computing 7:75-83.

Toledo, M.B. \& Bush, M.B. 2007. A mid-Holocene environmental change in Amazonian savannas. Journal of Biogeography 34: 1313-1326.

Türpe, A. M. 1984. Revision of the South American species of Schizachyrium (Gramineae). Kew Bulletin 39: 169-178.

Viana, P.L. \& Filgueiras, T.S. 2008. Inventário e distribuição geográfica das gramíneas (Poaceae) na Cadeia do Espinhaço, Brasil. Megadiversidade 4: 71-88.

Zuloaga, F.O., Morrone, O, Davidse, G., Filgueiras, T.S., Peterson, P.M., Soreng, R.J. \& Judziewicz, E.J. 2003. Catalogue of New World Grasses (Poaceae): III. Subfamilies Panicoideae, Aristidoideae, Arundinoideae, and Danthonioideae. Contributions from the United States National Herbarium 46: 1-662. 